ppi $201502 Z U 4645$

Esta publicación científica en formato digital es continuidad de la revista impresa ISSN-Versión Impresa 0798-1406 / ISSN-Versión on line 2542-3185Depósito legal pp $197402 Z$ U34
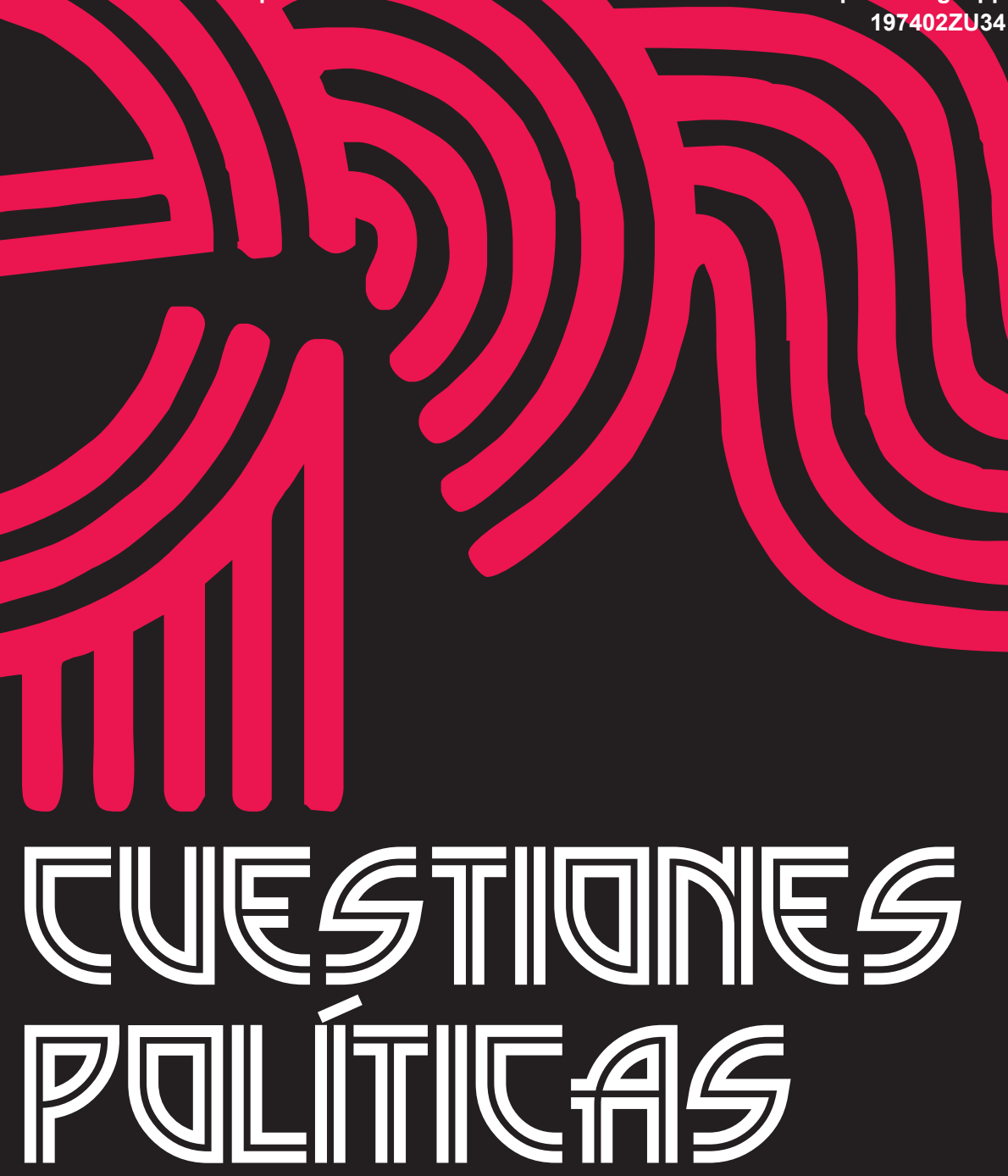

Instituto de Estudios Políticos y Derecho Público "Dr. Humberto J. La Roche" de la Facultad de Ciencias Jurídicas y Políticas de la Universidad del Zulia Maracaibo, Venezuela
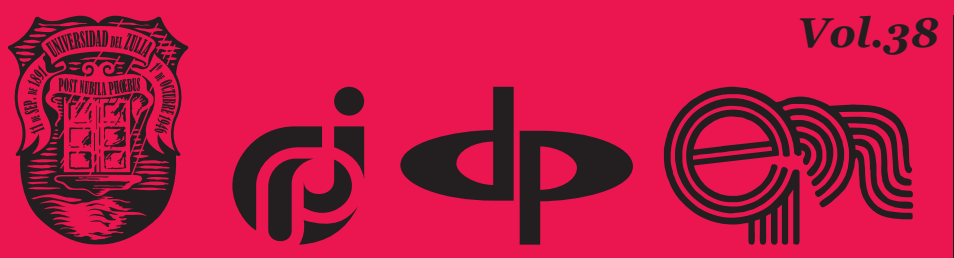

$N^{\circ}$ Especial 2da Parte 2020 


\title{
Jurisprudence of the European court of human rights in the choice of precautionary measures in criminal proceedings: legal realities and perspectives
}

\author{
DOI: https://doi.org/10.46398/cuestpol.382e.34
}

\author{
Svitlana Romantsova * \\ Igor Zinkovskyy ** \\ Ruslan Komisarchuk *** \\ Olha Balatska **** \\ Lesia Strelbitska *****
}

\section{Abstract}

The article deals with the problems of application of the decisions of the European Court of Human Rights (ECHR) in the selection of precautionary measures in criminal cases in accordance with Ukrainian law. Since the procedural legislation of Ukraine is currently not perfect in the framework of the establishment and regulation of the application of precautionary measures, the decisions of the ECHR serve as an indispensable regulator of this issue. The objective of the work is to study the peculiarities of the application of the jurisprudence of the European Court of Human Rights in the selection of precautionary measures in criminal proceedings. The subject of the investigation is the jurisprudence of the ECHR in the context of the choice of precautionary measures in the criminal process. The research methodology included and combined the dialectical method, logical and legal method, analysis, synthesis. By way of conclusion, the study shows that the practice of the ECHR is mandatory to take into account not only the courts but also the investigators and prosecutors, who legally have the right to request the court to apply such precautionary measures.

* Ph. D., Senior Lecturer, Department of Criminal Law, Faculty of Law, Lviv State University of Internal Affairs. ORCID ID: https:/orcid.org/oooo-0003-0888-5934. Email: s78romantsova@gmail.com

** Ph.D. candidate, Department of criminal procedure, detective, and operational search activity of National University "Odesa Law Academy". ORCID ID: https://orcid.org/oooo-0oo2-2867-3245. Email: zinkovskyyigorres@gmail.com

*** Ph. D., Associate Professor of Criminology Department of National University "Odesa Law Academy", ORCID ID: https://orcid.org/oooo-0002-2082-1207. Email: komisarrr@ukr.net

**** Ph. D., Senior Lecturer of Departments of civil-legal disciplines of I. Malynovskyi Institute of Law, The National University of Ostroh Academy. ORCID ID: https://orcid.org/oooo-ooo1-6439-5927. Email: olha.balatska@oa.edu.ua

*****Ph. D., Senior Lecturer of Departments of state-legal disciplines of National University of Ostroh Academy. ORCID ID: https://orcid.org/oooo-0003-3657-2783. Email: lesyastrelbitska@ukr.net 
Svitlana Romantsova, Igor Zinkovskyy, Ruslan Komisarchuk, Olha Balatska y Lesia Strelbitska 444

Jurisprudence of the European court of human rights in the choice of precautionary measures in criminal proceedings: legal realities and perspectives

Key words: European Court of Human Rights; European jurisprudence; precautionary measures; criminal process; legal reality of Ukraine.

\section{Jurisprudencia del tribunal europeo de derechos humanos en la elección de medidas cautelares en el proceso penal: realidades jurídicas y perspectivas}

\section{Resumen}

El artículo trata los problemas de aplicación de las decisiones del tribunal de derechos humanos de Europa (TEDH) en la selección de medidas cautelares en casos penales de conformidad con la legislación ucraniana. Dado que la legislación procesal de Ucrania actualmente no es perfecta en el marco del establecimiento y regulación de la aplicación de medidas cautelares, las decisiones del TEDH sirven como un regulador indispensable de esta cuestión. El objetivo del trabajo es estudiar las peculiaridades de la aplicación de la jurisprudencia del Tribunal Europeo de Derechos Humanos en la selección de medidas cautelares en procesos penales. El tema de la investigación es la jurisprudencia del TEDH en el contexto de la elección de medidas cautelares en el proceso penal. La metodología de investigación incluyó y combinó el método dialéctico, método lógico y legal, análisis, síntesis. A modo de conclusión, el estudio demuestra que la práctica del TEDH es obligatoria para tener en cuenta no solo a los tribunales sino también a los investigadores y fiscales, quienes legalmente tienen derecho a solicitar al tribunal la aplicación de tales medidas cautelares.

Palabras clave: Tribunal Europeo de Derechos Humanos;jurisprudencia europea; medidas cautelares; proceso penal; realidad legal de Ucrania.

\section{Introduction}

It is clear that the main task of the moment for humanity is to survive and successfully overcome the global crisis caused by the pandemic. However, in the fight against the virus, the ideological and cultural achievements of Western civilization must not be lost (Tkalych, Safonchyk, Tolmachevska, 2020). 
One of the defining characteristics of any legal system is the system of sources of law, which in turn is determined by the historical and mental characteristics of a state. Thus, in the Ukrainian legal tradition, there is still no final solution to the issue of referring judicial precedent to the sources of law, but in practice, this issue has received a positive result, primarily due to the authority of the European Court of Human Rights (ECHR).

This is confirmed by paragraph 1 of the Law of Ukraine "On Ratification of the Convention for the Protection of Human Rights and Fundamental Freedoms of 1950, First Protocol and Protocols No 2, 4, 7 and 11 to the Convention", according to which, in particular, Ukraine fully recognizes Article 46 Convention for the Protection of Human Rights and Fundamental Freedoms of 1950 on the recognition of the jurisdiction of the European Court of Human Rights in all matters concerning the interpretation and application of the Convention as binding and without the conclusion of a special agreement (On ratification of the Convention for the Protection of Human Rights and Fundamental Freedoms of 1950, the First Protocol and Protocols No 2, 4, 7 and 11 to the Convention, 1997).

Thus, in recognizing the jurisdiction of the ECtHR, Ukraine has made an unspoken commitment to follow the provisions set out in its decision. The use of the case-law of the European Court of Human Rights in the choice of precautionary measures in criminal proceedings is no exception, as in this situation, the protection of human rights is of paramount importance.

In some cases, national courts violate the rules established by the legislator, which in turn leads to illegal and unreasonable decisions on the choice of a measure of restraint for the suspect, accused, which violates his rights.

The case-law of the ECtHR orients our state to reform the entire legislative system, including the institution of precautionary measures, taking into account the principle of proportionality and fairness (Tertyshnyk, 2012).

Thus, the aim of the work is to study the peculiarities of the application of the case law of the European Court of Human Rights in the selection of precautionary measures in criminal proceedings. The object of the research is the case-law of the ECtHR in the context of the choice of precautionary measures in criminal proceedings. The subject of the study is the social relations that arise when choosing precautionary measures in criminal proceedings, taking into account the practice of the ECtHR. 
Svitlana Romantsova, Igor Zinkovskyy, Ruslan Komisarchuk, Olha Balatska y Lesia Strelbitska 446

Jurisprudence of the European court of human rights in the choice of precautionary measures in criminal proceedings: legal realities and perspectives

\section{Methodology}

The authors of this study are supporters of a humanistic, human-centered approach in legal science. Accordingly, the methodology of cognition of the object of this study is formed through the prism of the philosophy of humanism. Humanism is first of all a worldview that proceeds from the fact that man represents the highest, self-sufficient and self-conscious value, considers inhuman everything that contributes to his alienation.

Humanism can be viewed as a moral requirement only when humanity is manifested equally to all members of society. Therefore, he concretizes social justice, relying primarily on the properties inherent in all people, and requires the equality of all people in obtaining opportunities to realize their interests in the system of social relations.

The practical dimension of the philosophy of humanism is manifested, in particular, in the emergence of a human-centered approach in the social practices of people. The primary emphasis on the man himself, on his values for society and the state (and not vice versa), his rights and freedoms, led to the fact that the philosophy of anthropocentrism, in today's world has become more and more attractive to jurists who substantiated the fact that man and his life is a central element in building the rule of law. In general, this is the narrative that is preached in the vast majority of scientific sources in the field of law. We, of course, adhere to it.

Therefore in the methodological arsenal of jurisprudence, there are several detailed special methods of cognition of legal reality: historical and legal, formal legal (dogmatic), comparative-legal, sociological and legal, and the method of legal modeling. Undeservedly forgotten should be recognized the critical legal method of legal knowledge, which is not even mentioned in the overwhelming majority of modern textbooks on the theory of law.

From a philosophical point of view, criticism is a test of scientific judgment for its compliance with the truth. Therefore, to criticize is to question the truth of a particular judgment.

Scientific criticism is one of the most important methods of scientific knowledge, which consists in checking the correspondence of theoretical propositions to the criteria of truth, objectivity, provability, verifiability, etc. The role of criticism in its application to a new knowledge is especially important.

In science, only that knowledge is considered to have the right to exist, which previously passed through the crucible of criticism, having successfully passed this test. 
Criticism is an absolutely necessary and immanent condition for the development of science. The need to criticize and be constantly ready for criticism is one of the most important principles of the scientific community.

With regard to this study, not only controversial scientific positions, but also the current legislation, which does not correspond to modern realities in the field of human rights, are subjected to critical analysis.

Taking into account the person-centered approach in law, those legal concepts that do not take into account the social value of a person, his rights and freedoms are subject to critical analysis. In particular, representatives of criminal law science and practitioners sometimes take such positions. Such researchers consider punishment to be the main function of criminal liability. Often human rights in such cases leave legal formalities. At the same time, the educational function is of secondary importance for them. However, the European Court of Human Rights has developed clear recommendations that take into account the legal rights and interests of all participants in the criminal process. It is in this context that we are interested in the practice of the ECtHR in cases of the application of preventive measures to persons suspected of committing crimes.

\section{Literature Review}

The use of the case-law of the European Court of Human Rights in criminal proceedings in the selection of precautionary measures is covered in the works of such specialists as Gorbachevsky (2013), Simonovich (2011), Tertyshnyk (2012; 2016), Nor, and Shevchuk (2019), Kimlyk, (2017), Olashin, (2015), Pryluka (2019), Rybalko (2015), Taran, and Tsyupryk (2017), and Uvarov (2012).

Thus, Simonovich (2011); Tertyshnyk (2012; 2016); and Taran, and Tsyupryk (2017) are experts in the case-law of the ECtHR. They study the norms, principles, provisions that guide the ECtHR in decision-making. Moreover, they investigate the impact of ECtHR practice on the regulatory framework of European countries.

Besides, the work of Nor, and Shevchuk (2019); Rybalko (2015); Uvarov (2012) became the basis for studying current trends in the choice of precautionary measures in criminal proceedings both in Ukraine and abroad.

Arkusha, Korniienko, and Berendieieva (2019) in their article Criminal activity in Ukraine in the light of current conditions stated that the lack of regulation at the legislative level of relations in different areas of the life, impunity, as well as military instability - all of these promote the 
Svitlana Romantsova, Igor Zinkovskyy, Ruslan Komisarchuk, Olha Balatska y Lesia Strelbitska 448

Jurisprudence of the European court of human rights in the choice of precautionary measures in criminal proceedings: legal realities and perspectives

development of criminal activity, the creation of new and improvement of existing mechanisms, methods and criminal schemes. Thus, the precautionary measures is of prime importance in Ukraine.

Corruption for Ukraine is one of the most common types of crime. Thus, it should be determined whether the ECtHR has a solution to this problem. But before turning to the case-law of the ECtHR, let us analyze the doctrinal provisions of this crime, as the very nature of the crime already dictates the precautionary measures that may be appropriately applied. In studying the issue of corruption, the authors of this article relied on the next works of scientists: the article "Infrastructure of bribery in public official activity" by Tsytriak, Kalinina, and Hurina (2020); the article "The specifics of the appointment of forensic examinations in the investigation of corruptionrelated crimes committed in cyberspace" by Tishchenko, Bielik, and Samoilenko (2019).

Thus, in the legal doctrine there are works that study both the practice of the ECtHR and precautionary measures, but in the meantime, there is almost no work on a comprehensive analysis of the practice of the ECtHR on the choice of precautionary measures. This is what determines the relevance of the study.

\section{Results}

Respect for human and civil rights is a priority for the criminal justice authorities of each state in the investigation of crimes. International standards for the protection of human rights in criminal proceedings are a set of basic generally accepted and binding norms and principles that establish standardized rules of conduct for participants in criminal proceedings and are set out in international regulations, international agreements, and case-law of the ECtHR (Uvarov, 2012).

This especially applies to the rights and freedoms of such subjects of criminal proceedings as suspects and accused, including the application of measures to ensure criminal proceedings - precautionary measures.

Precautionary measures are measures of criminal procedural coercion of a preventive nature, accompanied by deprivation or restriction of liberties of the suspect, accused, and applied during criminal proceedings by authorized bodies and officials in respect of the suspect, accused to prevent attempts to prevent persons from and the court, to prevent the establishment of the truth, to continue criminal activity; to establish proper procedural conduct, as well as to ensure the implementation of procedural decisions (Gorbachevsky, 2013). 
Characteristic features of precautionary measures should be considered:

1. the legal nature of coercion.

2. application in the regulated procedure.

3. attachment to a person (relating to a specific person).

4. the possibility of application only to the suspect and the accused.

5. the presence of a clearly defined basis and purpose of application.

6. focus on monitoring the activities of the suspect, accused

7. practical implementation in the restriction of rights.

Part 1 of Article 176 of the Criminal Procedure Code of Ukraine (2012) (hereinafter - the Criminal Procedure Code) establishes an exhaustive list of precautionary measures, which includes personal obligation, personal bail, bail, house arrest, and detention.

As noted above, precautionary measures in criminal proceedings are directly related to the restriction of human rights and freedoms, so the practice of the ECtHR is of particular importance in their application.

At the same time, since detention is the most severe measure of restraint, and that is accompanied by restriction of the right to liberty, the main body of ECtHR decisions concerns the above-mentioned measure of restraint.

Article 5 of the European Convention for the Protection of Human Rights and Fundamental Freedoms (hereinafter - the Convention) provides that everyone has the right to liberty and security of person.

First of all, this article is actively used in criminal proceedings. Thus, the right to liberty and security of the person as a European standard of respect for human rights in criminal proceedings is a complex phenomenon, which includes:

- the right to freedom from arbitrary detention and detention; the right to be deprived of liberty only "based on law".

- the right to be immediately notified of the reasons for detention or detention; the right to be legally imprisoned only for a "reasonable period".

- the right to immediate judicial control over detention and detention.

- the right to be released from custody pending trial if there are guarantees of appearing in court; the right to challenge the lawfulness of detention or detention, and.

- the right to compensation for illegal detention or detention (Simonovich, 2011). 
Svitlana Romantsova, Igor Zinkovskyy, Ruslan Komisarchuk, Olha Balatska y Lesia Strelbitska Jurisprudence of the European court of human rights in the choice of precautionary measures in criminal proceedings: legal realities and perspectives

In particular, the case-law of the European Court of Human Rights is aimed at compliance with these aspects.

It should be noted that the choice and further application of a precautionary measure directly depend on the purpose and grounds for such an application.

According to Part 2 of Article 177 of the Criminal Procedure Code, the basis for the application of a precautionary measure is the existence of reasonable suspicion of committing a criminal offense, as well as the risks that give sufficient grounds to the investigating judge, the court to believe that the suspect, accused, convicted of this article.

Thus, in the decision in the case of Mironenko and Martenko v. Ukraine (2009), the ECtHR emphasized that the competent court reviewed not only the requirements of procedural law to resolve the issue of establishing a measure of restraint, but also the validity of suspicion as grounds for its application.

The ECtHR's injunctions in Letellier v. France (1991) state that suspicion must be based on facts or information that convince an objective observer of a possible crime by the person suspected (Nor and Shevchuk, 2019). This is duplicated in the decisions Ilgar Mammadov v. Azerbaijan (2014), Erdogdu v. Turkey (2000), Nechiporuk and Yonkalo v. Ukraine (2011).

Considering the complaint in Murray v. The United Kingdom of 28 October 1994, the ECtHR also emphasized that in determining the "degree of suspicion" the basis for choosing a measure of restraint in the form of detention could be a "lower threshold of reasonableness" for a particular category of crime (Kimlyk, 2017).

Part 1 of Article 178 of the Criminal Procedure Code contains a list of circumstances that are taken into account when choosing a measure of restraint. These circumstances also resonate with the case-law of the ECtHR given the following.

It is not uncommon to justify the choice of a measure of restraint is the severity of punishment (paragraph 2 of Part 1 of Article 178 of the Criminal Procedure Code). The ECtHR in Kalashnikov v. Russia (2002) has argued that the gravity of the offense and the severity of the sanction cannot be the sole or overriding justification for the application of coercion in the form of a restriction of the right, as such a person is presumed innocent until proven guilty in court (Pryluka, 2019.).

The ECtHR attaches great importance to the choice of a measure of restraint (paragraph 1, part 1 of Article 178 of the Criminal Procedure Code). In Labita v. Italy (2001), the ECtHR ruled that there was a risk of forgery of evidence and pressure on witnesses as a legal basis for choosing a measure of restraint. At the same time, there are no facts that could prove 
the existence of a real threat of the occurrence of this illegal behavior, which in turn makes it impossible to justify the application of a precautionary measure.

The judgment of Fox, Campbell, and Hartley v. The United Kingdom (1990) is also decisive in the circumstances relevant to the choice of measure of restraint, as it refers to the fact that a previous conviction for terrorist acts may increase suspicion of a terrorist offense, but cannot be the only justification for the suspicion. With this decision, the ECtHR emphasized that the reputation of a suspect or accused cannot be a predominant ground for restricting human rights and freedoms (Taran, and Tsyupryk, 2017).

Given the above, it can be concluded that, as a rule, the basis for the application of precautionary measures is a set of certain facts that serve as a basis for "reasonable suspicion".

The ECtHR also emphasizes the purpose of the application of precautionary measures. Thus, in the judgment in the case of Boicenco $\mathrm{v}$. Moldova (2006), the ECtHR stated that the national courts referred to the relevant provision of the legislative act, but the purpose of the precautionary measure was not identified, which in turn raised doubts about the threat of obstruction of proceedings, evasion of justice, new crimes, etc.

According to the author, these decisions have weight not only in the application of the precautionary measure in the form of detention, which was the basis of the complaints submitted to the ECtHR but also concerning other precautionary measures, as they express general requirements and requirements.

According to the legal position of the ECtHR, expressed in the judgments in the cases of Mancini v. Italy (2001), Buzadji v. The Republic of Moldova (2014), Korban v. Ukraine (2019), as well as detention, house arrest constitutes a deprivation of liberty. Thus, the ECtHR strongly recommends the application of the same criteria when assessing the appropriateness of coercion in the form of imprisonment, regardless of the place of application of the preventive measure (Shevchuk, 2020).

According to Part 1 of Article 181 of the Criminal Procedure Code, house arrest is a prohibition on a suspect or accused to leave the home around the clock or during a certain period of the day. This indicates the relationship of house arrest to the concept of housing. At the same time, the case-law of the European Court of Human Rights interprets this concept much more broadly than the Ukrainian legislator. Thus, the position of the ECtHR, enshrined in the decisions in the cases of Herrmann v. Germany (2012), Cola Est and others v. France (2002), Bock v. Germany (2010), emphasizes that, in addition to housing in the usual sense, it may apply and place of work (office space, branch or other building of the enterprise, institution, or organization). Also, more non-traditional facilities are also recognized as 

criminal proceedings: legal realities and perspectives

housing: motor homes (Buckley v. The United Kingdom (1996), Chapman v. The United Kingdom (2001)), huts and bungalows, regardless of the legality of their construction under national law (the case of Yordanov et al. v. Bulgaria (2018), Winterstein and others v. France (2013)), a gypsy tent (Buckley v. the United Kingdom (1996)) (Shevchuk, 2020).

Another significant type of coercion is bail as a form of precautionary measure in criminal proceedings. According to the author, the peculiarity of the pledge is the strict observance of the proportions between the committed crime, the guarantee of fulfillment of the duties imposed on the suspect, the accused and the amount of the pledge itself. No less important in this case is taking into account the financial situation of the person in respect of whom the precautionary measure in the form of collateral is chosen.

The latter can be illustrated by the judgment of the European Court of Human Rights in Mangouras v. Spain (2010), according to which the guarantees provided for in Article $5 \S 3$ of the Convention are intended to ensure the fulfillment of an obligation rather than compensation for losses. Thus, the mortgage amount should be determined taking into account the assets and liabilities of the suspect, accused and his relations with other persons who must ensure his safety. That is, the pledge should be determined by the degree of trust (confidence) at which the prospect of loss of the pledge or action against the guarantors, in the absence of his appearance in court, will be a sufficient deterrent to repel the person against whom bail has been applied, the desire in any way to prevent the establishment of the truth in criminal proceedings (Olashin, 2015).

In the judgment in the case of Yeloyev v. Ukraine (2008), the ECtHR went even further, arguing that the amount of bail should be determined not only by the property status of the person against whom the measure of restraint was taken but also by his social and family status. The ECtHR emphasized that, although the amount of bail should keep the suspect, accused of breaching his obligation in criminal proceedings, it should not lead to the loss of his means of decent living and the accommodation of his family members.

The case-law of the ECtHR also emphasizes the legality of sources of income in the case of bail, recognizing the decisions of national courts that refused to impose an appropriate precautionary measure due to the lack of evidence of the legality of receiving the claimed bail. This is stated, in particular, in the decision A.A. v. Switzerland (2019), stating that the circumstances of the case and the applicant's reputation had led the courts to reject his bail application, as the source of the money to be paid was unknown, and this would not be an adequate guarantee that the applicant would not disappear for fear of losing the pledge (Rybalko, 2015). 
Precautionary measures also include personal bail and personal commitment, which are equally important in achieving the purpose of criminal proceedings. At the same time, personal commitment is based on the effect of fear, and personal commitment is based on the effect of shame. Thus, it cannot be considered that these precautionary measures, when applied legally, restrict the rights of the individual, and therefore the need for intervention by the ECtHR, in this case, is reduced to a minimum.

It should be noted that human rights monitoring plays an important role in the application of precautionary measures.

In the judgment of Klass and Others v. The Federal Republic of Germany (1978) of 6 September 1978, the European Court of Human Rights defined the criteria and stages for verifying the lawfulness of the application of surveillance measures by persons carried out by the State. The ECtHR notes that one of the fundamental principles of a democratic society is the rule of law, a direct reference to which is contained in the preamble to the Convention. It follows from the rule of law, in particular, that the interference of the executive with human rights must be subject to effective supervision, which should normally be ensured by the judiciary. At the very least, it should be judicial oversight that best guarantees the independence, impartiality, and due process of legal procedures.

According to the author, the implementation of the above position of the ECtHR also takes place in the application of precautionary measures related to interference with fundamental human rights and freedoms guaranteed by the Convention, as such application must be under effective control, which should normally be provided by the judicial system in the form of judicial control.

\section{Conclusions}

Precautionary measures are the most severe measures of procedural coercion, restricting the constitutional rights of citizens, but should not violate the principle of the presumption of innocence. Precautionary measures should be considered an indisputably effective way of forcing a suspect or accused to perform his duties and providing a kind of safeguard for full and impartial criminal proceedings.

At the same time, the procedural legislation of Ukraine is currently not perfect within the framework of establishing and regulating the application of precautionary measures, so the decision of the ECtHR serves as an indispensable regulator of this issue. 

criminal proceedings: legal realities and perspectives

The practice of the ECtHR is aimed to humanize the criminal process, in particular within the application of precautionary measures, to introduce generally accepted European standards, as only the correct application of a precautionary measure will proportionally restrict the rights and freedoms of criminal proceedings. At the same time, the ECtHR aims to fulfill two main tasks: to restore the right of the person violated by national courts and to set a precedent that will serve as a basis for decisions by other courts.

Given the peculiarities of the choice of precautionary measures, the author also concludes that the practice of the ECtHR is mandatory to take into account not only the courts but also investigators and prosecutors, who are legally entitled to apply to the court for the application of such precautionary measures.

Thus, the practice of the ECtHR represents the perspective of the development of both European law in general and the national legislation of each signatory state to the Convention in the direction of strict observance of the rights and freedoms of the individual.

\section{Bibliographic References}

ARKUSHA, Larysa; KORNIIENKO, Maksym; BERENDIEIEVA, Anastasiia. 2019. "Criminal activity in Ukraine in the light of current conditions" In: Amazonia Investiga. Vol. 8, No. 24, pp. 386-391.

CRIMINAL PROCEDURE CODE OF UKRAINE. 2012. Verkhovna Rada de Ucrania. Available online. In: https://zakon.rada.gov.ua/laws/ show/4651-17\#Text. Consultation date: 28/12/2019.

EUROPEAN CONVENTION ON HUMAN RIGHTS. 1950. Convention for the Protection of Human Rights and Fundamental Freedoms. Available online. In: https://www.echr.coe.int/documents/convention_eng.pdf. Consultation date: 28/12/2019.

EUROPEAN COURT OF HUMAN RIGHTS. 1978. Judgment in the case of Klass and Others v. Germany Application. 6 September 1978, no. 5029/71. Available online. In: https://hudoc.echr.coe.int/rus?i=001-57510. Consultation date: 28/12/2019.

EUROPEAN COURT OF HUMAN RIGHTS. 1990. Judgment in the case of Fox, Campbell, and Hartley v. The United Kingdom. 30 August 1990, Appl. No. 12244/86; 12245/86; 12383/86) Available online. In: https://www.refworld.org/cases,ECHR,3ae6b6f9o.html. Consultation date: $28 / 12 / 2019$. 
EUROPEAN COURT OF HUMAN RIGHTS. 1991. Judgment in the case of Letellier v. France. 26 June 1991, (Application no. 12369/86). Available online. In: https://hudoc.echr.coe.int/tur\#\{\%22item id\%22:[\%22001-57678\%22]\}. Consultation date: 28/12/2019.

EUROPEAN COURT OF HUMAN RIGHTS. 1994. Judgment in the case of Murray v. The United Kingdom. 28 October 1994, (Application no. 14310/88). Available online. In: https://hudoc.echr.coe.int/rus\#\{ \%22itemid\%22:[\%22001-57895\%22]\}. Consultation date: 28/12/2019.

EUROPEAN COURT OF HUMAN RIGHTS. 1996. Judgment in the case of Buckley v. The United Kingdom. 29 September 1996, (Application no. 20348/92). Available online. In: https://hudoc.echr.coe.int/rus\#\{ \%22itemid\%22:[\%22001-58076\%22]\}. Consultation date: 24/06/2019.

EUROPEAN COURT OF HUMAN RIGHTS. 2000. Judgment in the case of Erdogdu v. Turkey. 15 June 2000, (Application no. 25723/94). Available online. In: https://hudoc.echr.coe.int/rus\#\{\%22item id\%22:[\%22001-58607\%22]\}. Consultation date: 24/06/2019.

EUROPEAN COURT OF HUMAN RIGHTS. 2001. Judgment in Labita v. Italy. 6 April 2000, (Application no. 26772/95). Available online. In: https:// hudoc.echr.coe.int/rus\#\{\%22itemid\%22:[\%22001-58559\%22]\}. Consultation date: $24 / 06 / 2019$.

EUROPEAN COURT OF HUMAN RIGHTS. 2001. Judgment in the case of Chapman v. The United Kingdom. 18 January 2001, (Application no. 27238/95). Available online. In: https://hudoc.echr.coe.int/eng\#\{ \%22itemid\%22:[\%22001-59154\%22]\}. Consultation date: 24/06/2019.

EUROPEAN COURT OF HUMAN RIGHTS. 2001. Judgment in the case of Mancini v. Italy. 2 August 2001 , (Application no. 44955/98). Available online. In: https://hudoc.echr.coe.int/fre\#\{\%22item id\%22:[\%22001-59626\%22]\}. Consultation date: 24/06/2019.

EUROPEAN COURT OF HUMAN RIGHTS. 2002. Judgment in the case of Cola Est and others v. France. 16 April 2002, (Application no. 37971/97). Available online. In: https://www.legal-tools.org/doc/5aefeo/pdf. Consultation date: 24/06/2019.

EUROPEAN COURT OF HUMAN RIGHTS. 2002. Judgment in the case of Kalashnikov v. Russia. 15.7.2002, (application no. 47095/99). Available online. In: https://hudoc.echr.coe.int/eng-press $\#\{\% 22 i t e m$ id\%22:[\%22003-587422-591161\%22]\} Consultation date: 12/08/2019.

EUROPEAN COURT OF HUMAN RIGHTS. 2008. Judgment in the case of Yeloyev v. Ukraine. 6 November 2008, (Application no. 17283/o2). 
Svitlana Romantsova, Igor Zinkovskyy, Ruslan Komisarchuk, Olha Balatska y Lesia Strelbitska 456 Jurisprudence of the European court of human rights in the choice of precautionary measures in criminal proceedings: legal realities and perspectives

Available online. In: https://hudoc.echr.coe.int/rus\#\{\%22item id\%22:[\%22001-89452\%22]\}. Consultation date: 12/08/2019.

EUROPEAN COURT OF HUMAN RIGHTS. 2009. Judgment in the case of Mironenko and Martenko v. Ukraine. 15 September 2011, (Application no. 24652/04). Available online. In: http://hudoc. echr.coe.int/app/conversion/pdf/?library=ECHR\&id=001106169\&filename $=$ 001-106169.pdf\&TID=ihgdqbxnfi. Consultation date: 12/08/2019.

EUROPEAN COURT OF HUMAN RIGHTS. 2010. Judgment in the case of Bock v. Germany. 19 January 2010, Application no. (22051/07). Available online. In: https://hudoc.echr.coe.int/fre\#\{\%22item id\%22:[\%22001-97268\%22]\}. Consultation date: 12/08/2019.

EUROPEAN COURT OF HUMAN RIGHTS. 2010. Judgment in the case of Mangouras v. Spain. 28 September 2010, (Application no. 12050/04). Available online. In: https://hudoc.echr.coe.int/rus\#\{\%22item id\%22:[\%22001-100686\%22]\}. Consultation date: 12/08/2019.

EUROPEAN COURT OF HUMAN RIGHTS. 2011. Judgment in the case of Nechiporuk and Yonkalo v. Ukraine. 21 de abril de 2011, (Solicitud № 42310/o4 ). Available online. In: https://www.legalaidreform.org/ european-court-of-human-rights/item/219-ecthr-case-summarynechiporuk-and-yonkalo-v-ukraine-21/04/2011/. Consultation date: 12/08/2019.

EUROPEAN COURT OF HUMAN RIGHTS. 2012. Judgment in the case of Herrmann v. Germany. 26 June 2012, (Application no. 9300/07). Available online. In: https://hudoc.echr.coe.int/eng\#\{\%22item id\%22:[\%22001-111690\%22]\}. Consultation date: 12/08/2019.

EUROPEAN COURT OF HUMAN RIGHTS. 2013. Judgment in the case of Winterstein and others v. France. 17 October 2013, (Application no. 27013/07). Available online. In: https://hudoc.echr.coe.int/fre\#\{\% 22itemid\%22:[\%22001-127539\%22]\}. Consultation date: 12/08/2019.

EUROPEAN COURT OF HUMAN RIGHTS. 2014. Judgment in the case of Buzadji v. The Republic of Moldova. 16 December 2014, (Application no. 23755/o7). ). Available online. In: https://hudoc.echr.coe.int/fre\#\{\% 22itemid\%22:[\%22001-148659\%22]\}. Consultation date: 12/08/2019.

EUROPEAN COURT OF HUMAN RIGHTS. 2014. Judgment in the case of Ilgar Mammadov v. Azerbaijan. 22 May 2014, (Application no. 15172/13). Available online. In: https://hudoc.echr.coe.int/fre?i=001-144124. Consultation date: 12/08/2019. 
EUROPEAN COURT OF HUMAN RIGHTS. 2018. Judgment in the case of Yordanov et al. v. Bulgaria. 6 September 2018, (application no. 3401/o9). Available online. In: https://hudoc.echr.coe. int/app/conversion/pdf/?library $=\mathrm{ECHR} \& \mathrm{id}=003-6180017-$ 8012606\&filename=Judgments\%20and\%20decisions\%20of\%20 06.09.18.pdf. Consultation date: 12/08/2019.

EUROPEAN COURT OF HUMAN RIGHTS. 2019. Judgment in the case of A.A. v. Switzerland. 7 January 2014, (Application no. 58802/12). Available online. In: https://hudoc.echr.coe.int/fre\#\{\%22item id\%22:[\%22001-139903\%22]\}. Consultation date: 12/08/2019.

EUROPEANCOURTOFHUMANRIGHTS.2019.JudgmentinthecaseofKorban v. Ukraine. 4 July 2019, (no. 26744/16). Available online. In: https:// hudoc.echr.coe.int/rus\#\{\%22itemid\%22:[\%22001-194188\%22]\}. Consultation date: 12/08/2019.

EUROPEAN COURT OF HUMAN RIGHTS. 2006. Judgment in the case of Boicenco v. Moldova. 11 July 2006 , (Application no. 41088/05). Available online. In: https://hudoc.echr.coe.int/fre?i=001-76295. Consultation date: 12/08/2019.

GORBACHEVSKY, Vitaly Yakovlevich. 2013. "Precautions in modern justice" In: Legal Journal of the National Academy of Internal Affairs. No. 1, pp. 215-219.

KIMLYK, Roman Vladimirovich. 2017. "Application of the case law of the European Court of Human Rights in criminal proceedings" In: Development of Jurisprudence Problems and Prospects. No. 1, pp. 107111.

LAW OF UKRAINE. 1997. On ratification of the Convention for the Protection of Human Rights and Fundamental Freedoms of 1950, the First Protocol and Protocols No 2, 4, 7 and 11 to the Convention. 1997, No. 475/97-BP. Available online. In: https://zakon.rada.gov.ua/laws/show/475/97\%Do\%B2\%D1\%80\#Text. Consultation date: 12/02/2020.

NOR, Vasyl T; SHEVCHUK, Marta I. 2019. "Reasonable suspicion as a basis for choosing a measure of restraint and extending its term: the case law of the European Court of Human Rights and Ukrainian realities" In: Law and society. Vol. 6, No. 2, pp. 173-187.

OLASHIN, Marina Mykolayivna. 2015. "The use of bail in criminal proceedings: theoretical and practical aspects" In: European perspectives. No. 5, pp. 116-121. 
Svitlana Romantsova, Igor Zinkovskyy, Ruslan Komisarchuk, Olha Balatska y Lesia Strelbitska 458 Jurisprudence of the European court of human rights in the choice of precautionary measures in criminal proceedings: legal realities and perspectives

PRYLUKA, Anna Yevheniivna. 2019. "The problem of proving the risks when choosing a measure of restraint in the form of detention" In: Scientific journal "Logos". No. 4, pp. 219-221.

RYBALKO, Vladimir. 2015. "Evaluative concepts used in the regulation of collateral as a precautionary measure" In: Historical and legal journal. Vol. 1, No. 5, pp. 130-135.

SHEVCHUK, Marta. 2020. "Features of the choice of precautionary measures in the form of house arrest and personal bail" In: Law and society. Vol. 2, No. 3, pp. 185-297.

SIMONOVICH, David Vladimirovich. 2011. European standards for ensuring human rights in the pre-trial stages of the criminal process in Ukraine. In: NikaNova. Kharkiv, Ukraine.

TARAN, Olena Viktorivna; TSYUPRYK, Igor Vladimirovich. 2017. "The case law of the European Court of Human Rights on issues related to manifestations of terrorism" In: Legal Journal of the National Academy of Internal Affairs. Vol. 2, No. 14, pp. 396-403.

TERTYSHNYK, Vladimir M. 2012. Application of the case law of the European Court of Human Rights and norms of international legal acts in the improvement of criminal justice in Ukraine. Dnipropetrovsk, Ukraine.

TERTYSHNYK, Vladimir M. 2016. "Implementation of legal positions and case law of the European Court of Human Rights in solving problems of criminal procedure law of Ukraine" In: Legal position. Vol. 1, No. 16, pp. 7-13.

TKALYCH, Maxym; SAFONCHYK, Oksana; TOLMACHEVSKA, Yuliia. 2020. "Derecho privado y derechos humanos: Nuevas realidades." In: DIXI. Vol. 22, No. 2, pp. 1-12.

TISHCHENKO, Valerii; BIELIK, Larysa; SAMOILENKO, Olena. 2019. "The specifics of the appointment of forensic examinations in the investigation of corruption-related crimes committed in cyberspace" In: Amazonia Investiga. Vol. 8, No. 24, pp. 280-287.

TSYTRIAK, Viktor; KALININA, Iryna; HURINA Dariia. 2020. "Infrastructure of bribery in public official activity" In: Amazonia Investiga. Vol. 9, No. 25, pp. 24-32.

UVAROV, Vladimir G. 2012. "Institute of precautionary measures under the new CPC of Ukraine in the context of international standards" In: Law and Society. No. 2, pp. 294-297. 

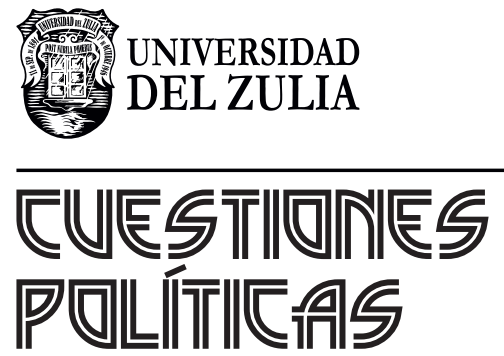

Vol.38 NEspecial

Esta revista fue editada en formato digital y publicada en diciembre de 2020, por el Fondo Editorial Serbiluz, Universidad del Zulia. Maracaibo-Venezuela 